\title{
Flexural Stress-Strain Behavior of RC Beams Made with Partial Replacement of Coarse Aggregates with Coarse Aggregates from Old Concrete
}

\author{
Part 1: 1:2:4 Ratio
}

\author{
Mahboob Oad \\ Department of Civil Engineering \\ Quaid-e-Awam University of Engineering, \\ Science \& Technology \\ Nawabshah, Pakistan \\ engrmahboob04@gmail.com \\ Bashir Ahmed Memon \\ Department of Civil Engineering \\ Quaid-e-Awam University of Engineering, \\ Science \& Technology \\ Nawabshah, Pakistan \\ Bashir_m@hotmail.com
}

\author{
Abdul Hafeez Buller \\ Quaid-e-Awam University of Engineering, \\ Science \& Technology \\ Nawabshah, Pakistan \\ engrabdulhafeezbuller@gmail.com
}

\author{
Noor Ahmed Memon \\ Department of Civil Engineering \\ Quaid-e-Awam University of Engineering, \\ Science \& Technology \\ Nawabshah, Pakistan \\ nahmedmemon@gmail.com
}

\begin{abstract}
Occupancy, particularly in urban areas, requires more space than ever. Space constraints need erection of high rise buildings in place of short height buildings. This need demolishing of old structures which creates huge quantities of demolished concrete. One of its best disposals is its use in new concrete. Therefore, this research work uses $50 \%$ replacement of natural coarse aggregates with coarse aggregates from old concrete to study the flexural stress-strain behavior of reinforced concrete beams. Total of 12 reinforced concrete beams $(900 \times 150 \times 150 \mathrm{~mm})$ were cast with $2 \# 4$ bars in tension and $2 \# 4$ bars in compression zones. Ordinary Portland cement with hill sand and crush aggregate was used in 1:2:4 proportions. Water cement ratio used is 0.54 . The beams were cast in two batches, one with $100 \%$ natural aggregates and another with $50 \%$ natural coarse aggregates replaced with coarse aggregates from old concrete. In each batch 3 beams were cured for 7 and 28 days respectively. After curing all beams were tested with central point load. The beams were monitored at regular intervals for load, displacement, strain and load until first crack. The beams under study were compared with the controlled specimen. The results were in good agreement with the normal concrete specimen. Maximum reduction in flexural stress is recorded as $8.8 \%$ for 7 -day cured beams and $5.52 \%$ for 28 -day cured specimen. Thus, the use of coarse aggregates from demolished concrete in new concrete is proved to be promising partial replacement of coarse aggregate in terms of flexural stress-strain relationship.
\end{abstract}

Keywords-flexural stress; green concrete; old concrete; recycled coarse aggregates; strain

\section{INTRODUCTION}

Migration from rural areas to city centers due to attractive opportunities of jobs and living style has posed a serious problem of accommodation around the globe. Due to limited residential space and limited space for associated facilities, construction industry is forced to opt for vertical construction instead of short height buildings. To this end, demolishing of short height buildings generates huge quantities of demolishing waste. This needs proper disposal, generally by dumping in reserved areas. The city centers already lack such space thus the problem of proper disposal emerges. One way of dealing this waste is by making use of it in new construction as whole or partial replacement of ingredients of new concrete. This will not only reduce the problem of waste management but also will help in saving the natural aggregates.

Attempts have been made to make use of various ingredients of construction waste by screening or detailed reprocessing. Re-use of bricks, glass, wood, old concrete, etc. has been done and it was observed that utilization of these materials as an aggregate in new constructions has promising effects. It was believed that filler portion of concrete is $70 \%$ to $80 \%$ of total concrete volume. This filler is believed to be the coarse aggregates. Also, it is believed that it has little effect on finished product, but research in the field reports differently. It reports that this component contributes much in determining stability, workability, durability and strength of the concrete. Two main issues with conventional concrete remain hot. First 
is the finding of alternative ingredient or material to enrich the strength and second is the use of waste obtained from demolishing of existing concrete structure. Earlier, recycled aggregates were used mainly in low utility applications such as general fill. Recently, these aggregates are used for intermediate utility application such as building foundations, roads etc.

Construction industry still has reservations on using recycled aggregates mainly due to doubts related to recycling methods, cost, machinery used in the process and the confidence in finished product. It is improving with time as research provides good insight of the use of such materials from different angles. However, it is also observed that scatter in reported observations in making use of recycled materials in concrete still demands more research in the area. Therefore, in this research paper, flexural stress-strain behavior of reinforced concrete beams made by using coarse aggregates from old concrete as partial replacement of coarse aggregates is studied. The research work is basically divided into two parts. The first part outcome is this research article, which deals with 1:2:4 mix and the second part will deal with rich concrete mix. Old concrete is collected from Nawabshah city. Large pieces of old concrete are then hammered to smaller pieces followed by sieving through $25 \mathrm{~mm}$ sieve. Using Ordinary Portland cement, hill sand, $50 \%$ crushed aggregates and 50\% coarse aggregates from old concrete, 12 reinforced concrete beams were prepared using 1:2:4 mix (M15 grade concrete). 2\#4 deformed bars were used in tension and compression zone respectively. \#3 deformed bars were used as stirrups at $150 \mathrm{~mm}$ center to center spacing throughout the length of beam. Six beams were prepared with $50 \%$ replacement of recycled coarse aggregates and six beams are prepared using $100 \%$ natural coarse aggregates to compare the results. Three beams of each group are cured for 7 days and three beams for 28 days in water. After curing time all beams were tested using central point load up to failure. Load, deflection and strain are recorded at regular intervals. The load at which the first crack is appeared is also recorded. The flexural stress is then computed using empirical methods. Obtained results are analyzed and presented in both tabular and graphical form.

\section{LITERATURE REVIEW}

Researchers remained actively engaged for a long time in finding alternative materials, which may be used as full or partial replacement of ingredient of concrete. To this end, glass, jute, husk, ash, old concrete, demolishing waste, polymers etc. have been studied by several scholars. But scatter in results is one of the key barriers to reach a solid conclusion for making use of these materials. This shows that there is still room for further research in the field. Use of demolished waste of old structures has been studied by different scholars but the difficulties associated with the use of demolished waste in new concrete demands more work to understand its behavior. Following literature review depicts the state of the art of the related work.

Author in [1] in a research paper on recent developments on the use of demolished concrete as coarse aggregates presented the details of the possibilities of use of demolished concrete as coarse aggregates and difficulties associated with the use of demolished concrete. Author concludes that the use of demolished concrete as partial replacement of natural coarse aggregates has promising effect. Author also concludes that if existing government policies are made more liberal and opportunities are introduced then the use of demolished concrete will increase. Authors in [2, 3] made use of demolished concrete as partial replacement of natural coarse aggregates in preparation of concrete cylinders of standard size. They used $50 \%$ replacement of natural coarse aggregates with aggregates from demolished concrete. In one study, authors developed relationship between the tensile strength versus weight of concrete while in the other study they evaluated and compared the tensile strength of concrete cylinders with concrete cylinders made with $100 \%$ natural coarse aggregates. They concluded that with the use of demolished concrete results in loss of only $5 \%$ tensile strength of the tensile strength of concrete cylinders made with $100 \%$ natural coarse aggregates. Authors in [4] studied the compressive strength of concrete cylinders using partial replacement of natural coarse aggregates with coarse aggregates from demolished concrete collected from Nawabshah city. They made seven batches of concrete cylinders by replacing $0 \%, 5 \%, 15 \%, 25 \%, 35 \%, 45 \%$ and $50 \%$ natural coarse aggregates with mix ratio of $1: 2: 4$ and $0.45-0.60 \mathrm{w} / \mathrm{c}$ ratio. They used a total of 54 cylinders with natural aggregates and 324 cylinders with recycled aggregates at curing age of 7,14 and 28 days. Based on laboratory test results, they observed maximum decrease in compressive strength equal to $26 \%$ with $50 \%$ replacement of natural aggregates. Therefore, they concluded that demolished concrete can effectively be used as coarse aggregates in new concrete works of low load.

Authors in [5] studied the flexural behavior of beams made with partial replacement of natural coarse aggregates with coarse aggregates from demolished concrete. They used beams with 1:2:4 concrete mix and 0.45-0.55 water cement ratio. 2\#4 deformed bars were used as main reinforcement and \#2 bars were used as stirrups. The beams were cast with $50 \%, 60 \%$, $70 \%$ and $80 \%$ replacement of natural coarse aggregates with coarse aggregates from demolished concrete. All beams were cured for 28 days followed by testing using central point load for flexural strength and cracking behavior. From the test results they observed minimum and maximum reduction in flexural strength equal to $12 \%$ and $26.6 \%$ respectively in comparison to beams made with $100 \%$ natural aggregates. Based on the research findings they concluded that $88 \%$ strength can be achieved with $50 \%$ replacement of natural aggregates with demolished waste concrete aggregates. Therefore, it can effectively be used in the areas of moderate or low load. Authors in [6] studied the flexural behavior of reinforced lightweight concrete beams made with oil palm shell. They used 6 underweight reinforced concrete beams with steel reinforcement ratios from $0.52 \%$ to $3.9 \%$ to study deflection characteristics, ductility, cracking behavior and end rotations. From the test results, they observed that the proposed product compares well with other lightweight concrete models. In [7], flexural behavior of reinforced concrete beams using foamed glass was carried out. Authors used foamed glass as partial replacement of coarse aggregates from $0 \%$ to $100 \%$ with 
increment of $25 \%$. In each beam 2 bars of $8 \mathrm{~mm}$ size were used to reinforce it. Authors observed that the density and compressive strength decreased with increase in dosage of foamed glass. Based on the test results they concluded that the presence of foamed glass in reinforced concrete beams improved the flexural load at which first crack appears but the deflection at failure was observed more than in the control concrete beams.

Authors in [8] studied the flexural behavior of reinforced concrete beams made with low calcium fly ash-based geo polymer as replacement of OPC. They tested four beams of $3 \mathrm{~m}$ length up to failure under static load. Based on test results they concluded that the use of the proposed material improves the flexural strength of reinforced concrete beams. Authors in [9] studied analytically and experimentally the flexural behavior of concrete beams using GFRP bars. They tested 10 beams with dimensions $2800 \mathrm{~mm} \times 300 \mathrm{~mm} \times 120 \mathrm{~mm}$ under four-point load up to failure. Using the test results and regression analysis, authors presented an empirical equation to evaluate the effective moment of inertia for FRP reinforced concrete beams. The proposed equation is compared with different code provisions and previous models for predicting. Based on the comparison they concluded that the developed equation was good for FRP reinforced concrete beams at high loads. Author in [10] used CFRP-NSM technique to retrofit the reinforced concrete beams and studied their flexural behavior. Based on the experimental observations he concluded the near surface mounted-carbon fiber reinforced polymer plates give better results than other techniques. Authors in [11] studied the flexural behavior of reinforced self-compacting concrete containing GGBFS. Their study used simply supported beams $2 \mathrm{mx} 0.1 \mathrm{mx} 0.1 \mathrm{~m}$ with HYSD bars with different percentages of GGBFS $(0 \%, 30 \%, 40 \%$ and $50 \%)$ as partial cement replacement. They compared the test results with the results of control concrete specimens and found that the new product has promising effects on the strength and flexural behavior of reinforced concrete beams. Authors in [12] used steel fibers to study the enhancement in flexural capacity of reinforced high strength concrete beams. They used $35 \mathrm{~mm}$ long and $0.5 \mathrm{~mm}$ diameter steel fibers in dosage of $1 \%$ and $2 \%$ to cast and test high strength concrete beams. The test results showed the improved properties of their proposed model. In [13] GGBS is used as partial replacement of OPC to study the flexural behavior of RC beams. Authors used 8 reinforced concrete beams with and without GGBS in dosage of $40 \%$ with Glenium B-233 super plasticizer. The test results of specimen cured at 28 and 56 days revealed comparable results with control concrete beams.

\section{MODEL DESCRIPTION AND TESTING}

In this research work a total of twelve reinforced concrete beams with dimensions of $900 \mathrm{~mm} \times 150 \mathrm{~mm} \times 150 \mathrm{~mm}$ are cast. Out of these beams, six were prepared using old demolished concrete in $50 \%$ proportion, whereas the other six beams were cast using $100 \%$ natural coarse aggregates to compare the results. Old concrete in the shape of large pieces is collected from Nawabshah city (Figure 1(a)). These large pieces are then hammered to size approximately equal to $25 \mathrm{~mm}$ (Figure 1(b)), followed by sieving of the material through $25 \mathrm{~mm}$ sieve. Both natural coarse aggregates and coarse aggregates from old concrete with hill sand and ordinary Portland cement are proportioned in 1:2:4 ratio. Water cement ratio used is 0.54 . $2 \# 4$ deformed bars are used in both tension and compression zones respectively along with stirrups of \#3 deformed bars at $150 \mathrm{~mm}$ center to center.

The beams B1, B2, B3 (with 50\% RCA) and B7, B8, B9 (with $0 \% \mathrm{RCA}$ ) were cured for 7 days. The beams B4, B5, B6 (with 50\% RCA) and B10, B11, B12 were cured for 28 days. After curing period, strain dumic pads were fixed on the sides of the beams in three positions i.e. one at center and two layers one above and one below the center layer with $38 \mathrm{~mm}$ gap between layers (Figure 2). The beams were tested in universal load testing machine with central point load (Figure 3). Load, deflection and strain were measured at regular intervals. Flexural stress is then computed using numerical expression for flexural strength.

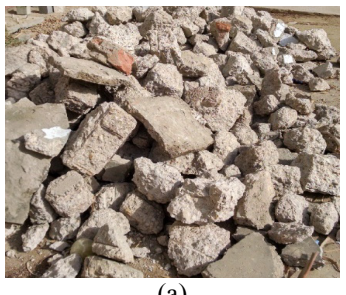

(a)

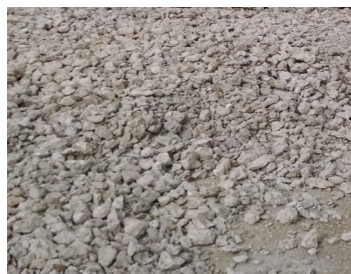

(b)
Fig. 1. (a) Old concrete, (b) RCA hammered to $25 \mathrm{~mm}$

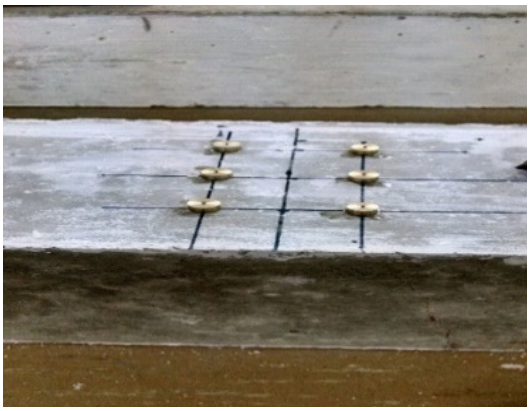

Fig. 2. Dumic pads

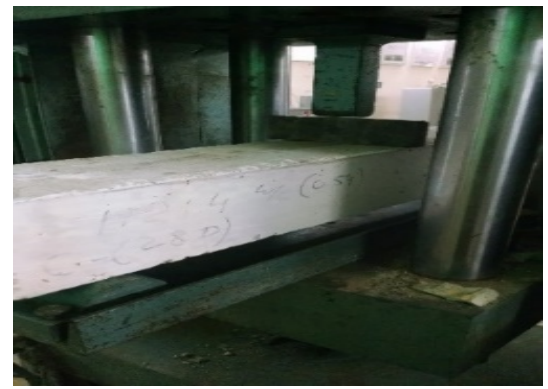

Fig. 3. Beam under central point load

\section{RESULTS AND DISCUSSION}

All the beams are tested using a Universal Load Testing machine with central point load applied gradually. Load, deflection and strain were recorded at regular intervals of 
approximately $2500 \mathrm{~N}$. Load is applied till beam failure. All beams were carefully monitored during the loading process and the load at which first crack appeared was recorded. Figure 4 shows the first crack in 3 beams. The crack appeared near support with diagonal orientation. Similar pattern of first crack is observed in the other beams but with different locations between supports. After the first crack the load was increased till beam failure. Failure of almost all beams started with widened crack starting from center and progressed diagonally up to support location. Figure 5 shows the failure of selected beams. Crack pattern shows beams failed in shear. From recorded load flexural stress is then evaluated by numerical expression given bellow

$$
\sigma_{f}=\frac{3 P L}{2 b d^{2}}
$$

where $\mathrm{P}$ is the central point load on beam, $\mathrm{L}$ is the length, $\mathrm{b}$ is breadth, $d$ is depth of beam and $f$ denotes flexural strength.

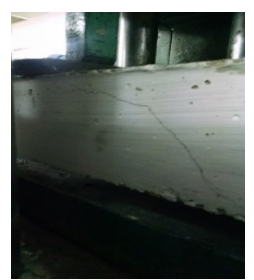

Fig. 4.

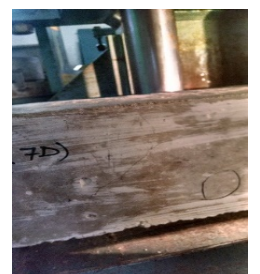

First crack in beams B1, B3 and B4

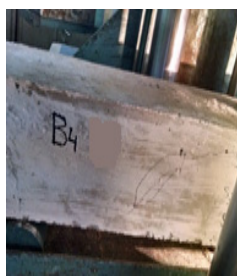

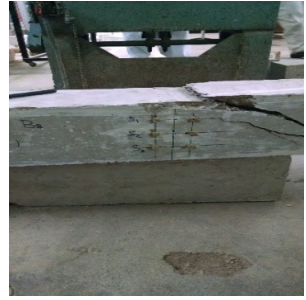

Fig. 5.

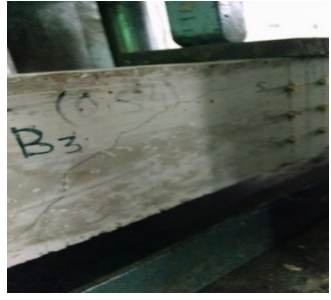

Failure of beams
Dial readings for strain at all locations were converted into strain by multiplying dial constant, followed by evaluation of average strain for all beams. Deflection values recorded at intervals of approximately $2500 \mathrm{~N}$ except for failure load were also recorded. Flexural stress and strain are plotted in Figure 6 for beams cast with $50 \%$ coarse aggregates from old concrete and cured for 7 days. The plot shows similar pattern of flexural stress versus strain, however, beam B2 showed slight downward jerk in strain between flexural stress values of $15 \mathrm{~N} / \mathrm{mm}^{2}$ and $20 \mathrm{~N} / \mathrm{mm}^{2}$. The cause could be that the coarse aggregate from old concrete is weaker. The jerk is less than 5\% and therefore was ignored. The maximum flexural stress observed in this B3 was $30.16 \mathrm{~N} / \mathrm{mm}^{2}$ which was about $16.73 \%$ higher than that of beam B1 and $13.35 \%$ higher than that of beam B2. The deflection observed in all three beams was in the range of $5.1-5.2 \mathrm{~mm}$. The value obtained is $2 \%-4 \%$ higher than the approximate value given by ACI-318 provisions $(L / 180)$. Flexural stress versus strain for beams B4 to B6, cast with 50\% coarse aggregates from old concrete and cured for 28 days, is plotted in Figure 7.

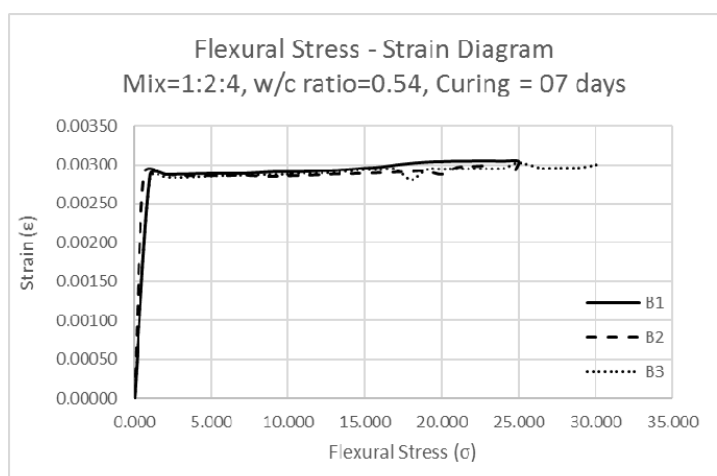

Fig. 6. Flexural stress-strain behavior of beams B1-B3 (7 days of curing with $50 \%$ RCA)

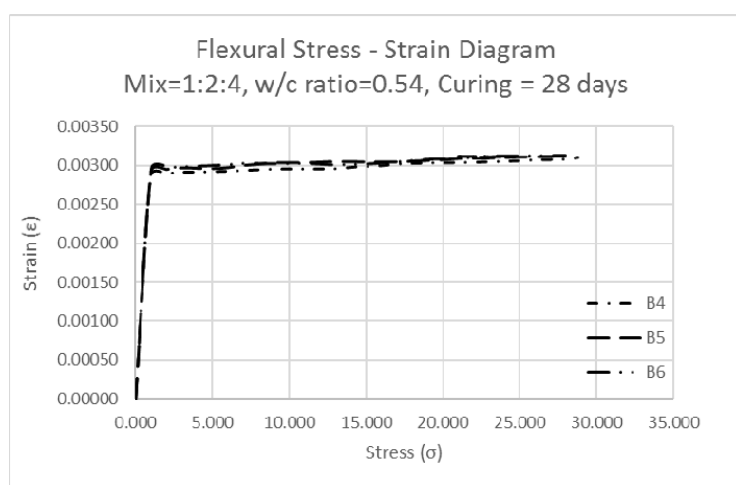

Fig. 7. Flexural stress-strain behavior of beams B4-B6 (28 days of curing with $50 \%$ RCA)

The pattern of all graphs is approximately the same with approximately same maximum value. Maximum flexural stress in all three beams is recorded as $28.81 \mathrm{~N} / \mathrm{mm}^{2}$. Maximum deflection in beams is recorded equal to $4.17 \mathrm{~mm}$ which is within permissible values of ACI 318 provisions. Figures 8 and 9 show the flexural stress versus strain of beams cast with total natural aggregates and cured for 7 and 28 days respectively. Three beams in each group were used. Figure 10 presents the flexural stress and strain for 7-day cured beams made with 50\% RCA and 7-day cured beams made with $100 \%$ natural aggregates. It is clear from the figure that beams made with allnatural aggregates obtained more flexural stress and less strain than beams made with $50 \%$ RCA. Peak values of maximum load, deflection, flexural stress, strain and load at which first crack appeared are given in Table I for beams made with 50\% RCA (7-day curing) and Table III presents the same for beams made with all-natural aggregates. The average of these values and the difference percentage with control specimen are given in Table V. It can be noticed that beams made with 50\% RCA and cured for 7 days showed $8.8 \%$ reduction in maximum load and $20.47 \%$ less deflection. The same percentage reduction in flexural stress was recorded. However, these beams showed $12.99 \%$ more strain than control specimen. The first crack appeared in these beams at $8.97 \%$ lesser load than control specimen. Figure 11 presents the same comparison as in Figure 10 but for 28-day cured beams. Peak values of parameters under consideration are given in Tables II and IV for $50 \%$ RCA 
beams and $0 \%$ RCA beams respectively. Average values of these parameters along with percentage difference are given in Table VI. The beams made by $50 \%$ replacement of coarse aggregates showed $5.53 \%$ reduction in maximum load compared to beams made with $100 \%$ natural coarse aggregates. Although this is surprising, these beams showed $40.8 \%$ less deflection than the control specimen. A reduction of $5.52 \%$ was recorded in flexural stress. Also, these beams showed $12.25 \%$ more strain than control specimen. These beams showed first crack at $18.52 \%$ less load than beams made with all-natural coarse aggregates.

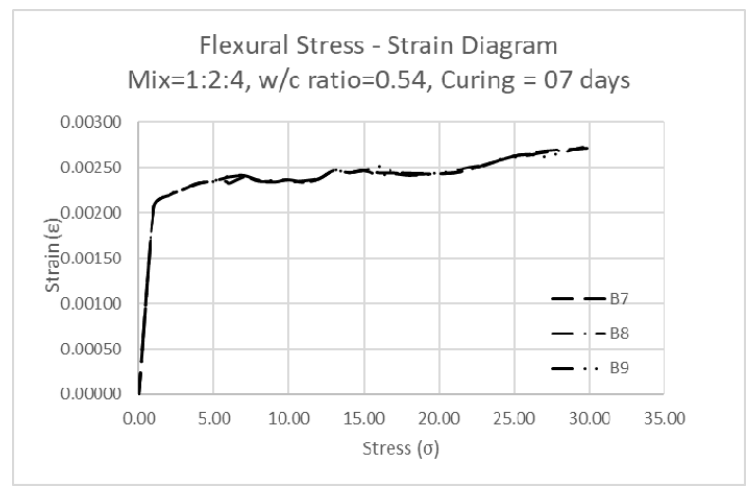

Fig. $8 . \quad 7$ days cured beams $(0 \%$ RCA $)$

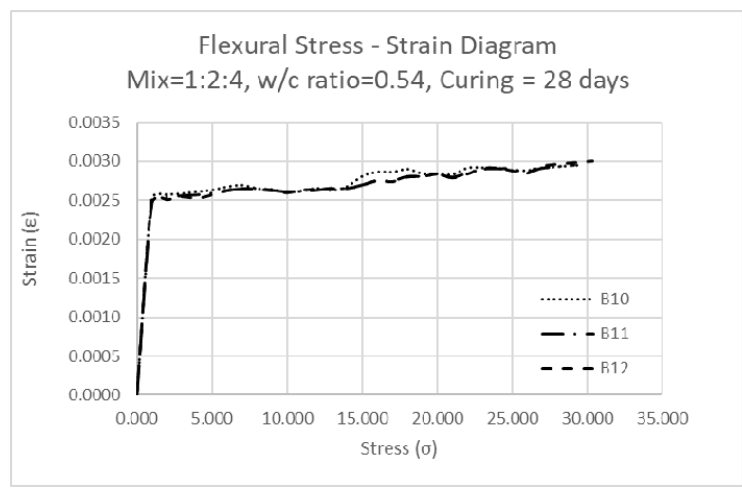

Fig. 9. 28 days cured beams $(0 \%$ RCA)

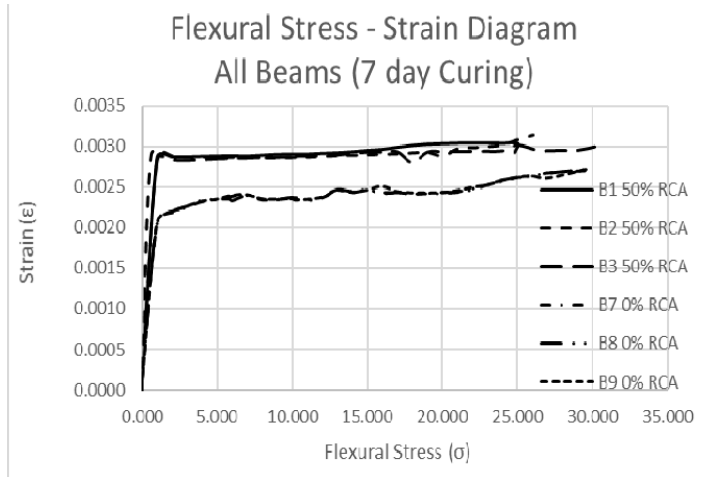

Fig. 10. Flexural stress - strain comparison of all beams (7-day curing)

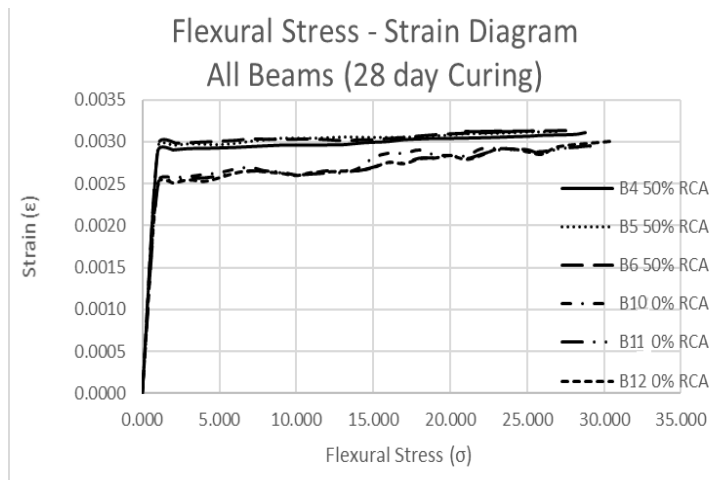

Fig. 11. Flexural stress-strain comparison of all beams (28-day curing)

TABLE I. PEAK VALUES OF 7 DAYS CURED 50\% RCA BEAMS

\begin{tabular}{|c|c|c|c|c|c|}
\hline Beam & $\begin{array}{c}\text { Max Load } \\
\mathbf{( N )}\end{array}$ & $\begin{array}{c}\text { Deflection } \\
(\mathbf{m m})\end{array}$ & $\begin{array}{c}\text { Stress } \\
\left(\mathbf{N} / \mathbf{m m}^{\mathbf{2}}\right)\end{array}$ & Strain & $\begin{array}{c}\text { Load at } \\
\text { first crack } \\
\mathbf{( N )}\end{array}$ \\
\hline B1 & 65098 & 5.13 & 25.01 & 0.00305 & 50031 \\
\hline B2 & 65069 & 5.12 & 26.03 & 0.00314 & 45018 \\
\hline B3 & 75401 & 5.22 & 30.16 & 0.00302 & 55322 \\
\hline
\end{tabular}

TABLE II. PEAK VALUES OF 28 DAYS CURED 50\% RCA BEAMS

\begin{tabular}{|c|c|c|c|c|c|}
\hline Beam & $\begin{array}{c}\text { Max Load } \\
(\mathbf{N})\end{array}$ & $\begin{array}{c}\text { Deflection } \\
(\mathbf{m m})\end{array}$ & $\begin{array}{c}\text { Stress } \\
\left(\mathbf{N} / \mathbf{m m}^{\mathbf{2}}\right)\end{array}$ & Strain & $\begin{array}{c}\text { Load at } \\
\text { first } \\
\text { crack (N) }\end{array}$ \\
\hline B4 & 72030 & 4.17 & 28.81 & 0.00338 & 55043 \\
\hline B5 & 68038 & 3.85 & 27.22 & 0.00336 & 50031 \\
\hline B6 & 69890 & 3.96 & 27.96 & 0.00326 & 55041 \\
\hline
\end{tabular}

TABLE III. PEAK VALUES OF 7 DAYS CURED $0 \%$ RCA BEAMS

\begin{tabular}{|c|c|c|c|c|c|}
\hline Beam & $\begin{array}{c}\text { Max Load } \\
(\mathbf{N})\end{array}$ & $\begin{array}{c}\text { Deflection } \\
(\mathbf{m m})\end{array}$ & $\begin{array}{c}\text { Stress } \\
\left(\mathbf{N} / \mathbf{m m}^{\mathbf{2}}\right)\end{array}$ & Strain & $\begin{array}{c}\text { Load at } \\
\text { first } \\
\text { crack (N) }\end{array}$ \\
\hline B7 & 74606 & 6.46 & 29.84 & 0.00271 & 55000 \\
\hline B8 & 73985 & 6.46 & 29.59 & 0.00272 & 55080 \\
\hline B9 & 73980 & 6.53 & 29.59 & 0.00272 & 55105 \\
\hline
\end{tabular}

TABLE IV. PEAK VALUES OF 28 DAYS CURED $0 \%$ RCA BEAMS

\begin{tabular}{|c|c|c|c|c|c|}
\hline Beam & $\begin{array}{c}\text { Max Load } \\
\text { (N) }\end{array}$ & $\begin{array}{c}\text { Deflectio } \\
\mathbf{n}(\mathbf{m m})\end{array}$ & $\begin{array}{c}\text { Stress } \\
\mathbf{( N / \mathbf { m m } ^ { 2 } )}\end{array}$ & Strain & $\begin{array}{c}\text { Load at } \\
\text { first } \\
\text { crack (N) }\end{array}$ \\
\hline B10 & 73506 & 6.71 & 29.40 & 0.00295 & 45000 \\
\hline B11 & 72810 & 6.74 & 29.12 & 0.00295 & 45021 \\
\hline B12 & 75925 & 6.79 & 30.37 & 0.00300 & 45070 \\
\hline
\end{tabular}

TABLE V. AVERAGE VALUES OF 7 DAY CURED BEAMS

\begin{tabular}{|c|c|c|c|c|c|c|}
\hline \# & Beam & $\begin{array}{c}\text { Max } \\
\text { Load } \\
(\mathbf{N})\end{array}$ & $\begin{array}{l}\text { Deflection } \\
\quad(\mathbf{m m})\end{array}$ & $\begin{array}{c}\text { Stress } \\
\left(\mathbf{N} / \mathbf{m m}^{2}\right)\end{array}$ & Strain & $\begin{array}{l}\text { Load at } \\
\text { first crack } \\
\text { (N) }\end{array}$ \\
\hline \multirow{3}{*}{1} & $\mathrm{~B} 1$ & \multirow{3}{*}{67665.00} & \multirow{3}{*}{5.16} & \multirow{3}{*}{27.07} & \multirow{3}{*}{0.00307} & \multirow{3}{*}{50123.67} \\
\hline & B2 & & & & & \\
\hline & B3 & & & & & \\
\hline \multirow{3}{*}{2} & B7 & \multirow{3}{*}{74190.33} & \multirow{3}{*}{6.48} & \multirow{3}{*}{29.68} & \multirow{3}{*}{0.00272} & \multirow{3}{*}{55061.67} \\
\hline & B8 & & & & & \\
\hline & B9 & & & & & \\
\hline \multicolumn{2}{|c|}{$\%$ Value } & 91.20 & 79.53 & 91.20 & 112.99 & 91.03 \\
\hline \multicolumn{2}{|c|}{$\%$ Difference } & 8.80 & 20.47 & 8.80 & -12.99 & 8.97 \\
\hline
\end{tabular}


TABLE VI. AVERAGE VALUES OF 28 DAY CURED BEAMS

\begin{tabular}{|c|c|c|c|c|c|c|}
\hline \# & Beam & $\begin{array}{c}\text { Max } \\
\text { Load } \\
(\mathrm{N}) \\
\end{array}$ & $\begin{array}{l}\text { Deflection } \\
\quad(\mathrm{mm})\end{array}$ & $\begin{array}{c}\text { Stress } \\
\left(\mathrm{N} / \mathbf{m m}^{2}\right)\end{array}$ & Strain & $\begin{array}{c}\text { Load at } \\
\text { first } \\
\text { crack (N) }\end{array}$ \\
\hline \multirow{3}{*}{1} & B4 & \multirow{3}{*}{69986.00} & \multirow{3}{*}{3.99} & \multirow{3}{*}{28.00} & \multirow{3}{*}{0.00333} & \multirow{3}{*}{53371.67} \\
\hline & B5 & & & & & \\
\hline & B6 & & & & & \\
\hline \multirow{3}{*}{2} & $\mathrm{~B} 10$ & \multirow{3}{*}{74080.33} & \multirow{3}{*}{6.75} & \multirow{3}{*}{29.63} & \multirow{3}{*}{0.00297} & \multirow{3}{*}{45030.33} \\
\hline & B11 & & & & & \\
\hline & $\mathrm{B} 12$ & & & & & \\
\hline \multicolumn{2}{|c|}{$\%$ Value } & 94.47 & 59.20 & 94.48 & 112.25 & 118.52 \\
\hline \multicolumn{2}{|c|}{$\%$ Difference } & 5.53 & 40.80 & 5.52 & -12.25 & -18.52 \\
\hline
\end{tabular}

From the obtained results it is concluded that the coarse aggregates from old concrete have promising effect on the strength of new reinforced concrete members. Although the water absorption of these aggregates is higher than the natural coarse aggregates yet the percentage reduction in flexural strength is only $8.8 \%$ which even can be improved by controlling water-cement ratio or steel quantity. It is also observed that beams made with $50 \%$ replacement of natural coarse aggregates with coarse aggregates from old concrete observed about $41 \%$ less deflection than control specimen with no further reduction in flexural strength. This phenomenon shows better performance of the beams but needs further indepth evaluation and analysis of this effect with larger numbers of beams and considering water cement ratios. These beams also showed about 13\% more strain when compared with control specimen. This is also a very good sign as it proves the ductility of the members and it will give more warning time before failure. The appearance of first crack is recorded at about $9 \%$ less load than that of control specimen but the reduction in flexural strength, peak load and failure mode of beams are in good agreement with the control specimen (Figure 12). Therefore, $50 \%$ replacement of natural coarse aggregates may comfortably be used initially in those areas where less load is applied on the structural members.
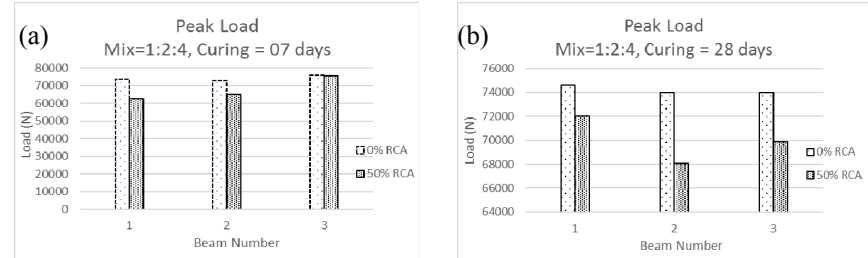

Fig. 12. Peak load for $0 \%$ and $50 \%$ RCA beams. (a) 7-day curing, (b) 28 day curing

\section{CONCLUSION}

This research paper presents experimental evaluation of reinforced concrete beams made with $50 \%$ replacement of natural coarse aggregates with coarse aggregates from old concrete. Twelve reinforced concrete beams were prepared in two groups. In one group beams were cast with $50 \%$ RCA, whereas in the second group, beams were prepared with allnatural aggregates and were termed as control specimen for result comparison. In each group three beams were cured for 7 days and the other three for 28 days. Peak load, flexural strength, strain, deflection, load at which first crack occurs and failure mode were studied by testing beams under central point load. Load was applied gradually up to failure. Comparison and analysis of results showed that the beams observed maximum of $8.8 \%$ average reduction in flexural strength for cured beams for 7 days and average reduction of $5.52 \%$ for cured beams for 28 days. Minimum strain gain of $12.25 \%$ was observed in $28-$ day cured beams. The average deflection in these beams was recorded lower than the control specimen's. This parameter needs further study for better conclusions. Although first crack appeared at lower load than control specimen, yet cracking pattern and failure mode are in good agreement with the control specimen. Therefore, it is concluded that the use of coarse aggregates from old concrete has promising impact on parameters studied in this research work and can be used comfortably initially in low loads.

\section{REFERENCES}

[1] B. A. Memon, "Recent Development on Use of Demolished Concrete as Coarse Aggregates", International Journal of Emerging Technology and Innovative Engineering, Vol. 2, No. 1, pp. 1-11, 2016

[2] S. Tanwani, B. A. Memon, "Relationship between Weight and Tensile Strength of Concrete Cylinders Made by Partial Replacement of Coarse Aggregates from Old Concrete", International Journal of Engineering Inventions, Vol. 5, No. 06, pp. 1-9, 2016

[3] S. Tanwani, B. A. Memon, "Tensile Strength of Concrete Cylinders Made By Partial Replacement Of Natural Coarse Aggregates With Coarse Aggregates From Old Concrete", International Journal of Emerging Technology and Innovative Engineering, Vol. 1, No. 4, 2015

[4] M. Oad, B. A. Memon, "Compressive Strength of Concrete Cylinders using Coarse Aggregates from Old Concrete", 1st National Conference on Civil Engineering (NCCE 2013-14)-(Modern Trends and Advancements), April 28-29, 2014

[5] B. A. Memon, G. S. Bhatti. "Flexural Behavior of Beam made by Partial Replacement of Natural Aggregates with Coarse Aggregates from Old Concrete", International Journal of Engineering Sciences \& Research Technology, Vol. 3, No. 5, pp. 52-61, 2014

[6] D. C. L. Teo, M. A. Mannan, J. V. Kurian, "Flexural Behavior of Reinforced Light Weight Concrete Beams Made with Oil Palm Shell”, Journal of Advanced Concrete Technology, Vol. 4, No. 3, pp. 459-468, 2006

[7] J. M. Khatib, S. Shariff, E. M. Negim, "Effect of Incorporating Foamed Glass on the Flexural Behavior of Reinforced Concrete Beam", World Applied Sciences Journal, Vol. 19, No. 1, pp. 47-51, 2012

[8] S. Kumaravel, S. Thirugnanasambandam, "Flexural "Behavior of Reinforced Low Calcium Fly Ash based Geopolymer Concrete Beam", Global Journal of Researches in Engineering - Civil and Structural Engineering, Vol. 13, No. 8, pp. 8-13, 2013

[9] M. A. Adam, M.Said, A. A. Mahmoud, A. S. Shanour, "Analytical and experimental flexural behavior of concrete beams reinforced with glass fiber reinforced polymers bars". Construction and Building Materials, Vol. 84, pp. 354-366, 2015

[10] S. Al-Obaidi, Behavior of Reinforced Concrete Beams Retrofitted in Flexure Using CFRP-NSM Technique, MSc Thesis, Portland State University, 2015

[11] M. Mithra, P. Ramanathan, P. Muthupriya, R. Venkatasubramani, "Flexural Behavior of Reinforced Self Compacting Concrete Containing GGBFS". International Journal of Engineering and Innovative Technology, Vol. 1, No. 4, pp. 124-129, 2012

[12] N Harsha Vardan, K. Kartheek Babu, A. Annadurai, "Enhancing Flexural Capacity of Steel Fiber Reinforced High Strength Concrete Beams", International Journal of Scientific Research Engineering Technology, Vol. 2, No. 2, pp. 57-61, 2016

[13] S. P. Sangeetha, P. S. Joanna, "Behavior of Reinforced Concrete Beams with Partial Replacement of GGBS", American Journal of Engineering Research, Vol. 3, No. 1, pp. 119-127, 2014 